\title{
Comparative Analysis of ART in the EU: Cross-border Reproductive Medicine
}

\author{
GORDANA KOVAČEK STANIĆ
}

\begin{abstract}
The need for cross-border reproductive medicine exists for several reasons. Some are due to the fact that some states do not permit particular ART procedures; thus couples travel to the state where needed procedure is allowed (surrogate motherhood, embryo donation, posthumous fertilization). Other situations are due to the fact of who is entitled to ART procedures. In some states ART procedures are not allowed to same-sex couples or a single woman. The consequence of the cross-border reproductive medicine might be that the born child becomes parentless ("limping legal parentage") and stateless. Since the best interest of the child is the paramount principle in contemporary family law, it is most important to find solutions for these situations. The most complicated issues are the consequences arising from international surrogacy arrangements. The Hague Conference on private international law is working on these issues trying to find the best solutions.
\end{abstract}

KEYWORDS: - cross-border - reproductive medicine - child • parentage $\cdot$ Hague Conference $\cdot$ EU

CorRespondence Address: Gordana Kovaček Stanić, Ph.D., Professor, University of Novi Sad, Faculty of Law, Dr. Zorana Đinđića 1, 21000 Novi Sad, Serbia, email: gkstanic@gmail.com.

DOI 10.18690/8.5-23(2015)

ISSN 2463-7955 Print (C) 2015 LeXonomica Press

Available online at http://journals.lexonomica.press. 
G. Kovaček Stanić: Comparative Analysis of ART in the EU: Cross-border Reproductive Medicine

The legislation of EU countries differs in the regulation of ART (artificial reproduction technologies) in a way that some countries have liberal and some have restrictive approach concerning regulation of particular procedures. The great difference exists in allowing or not some procedures, for instance, surrogate motherhood, embryo donation, posthumous fertilization.

The consequence of the existing differences in regulation is that some couples need to use cross-border reproductive medicine in order to get the needed treatment. This new phenomenon is sometimes called "reproductive tourism". Couples who need a procedure which is not allowed in their own country, or it is not available, or it is more expensive, go to a country in which the procedure is allowed or more available. If the child is born and the couple wants to return to their country, different problems arise. One of the most important is the legal parentage of the child.

It is very important to protect rights and interest of the child born applying the ART. "This would include seeking to eliminate "limping" legal parentage, ensuring children are able to acquire nationality, ensuring their right to know their identity is secured and putting in place procedures to ensure that they are protected from harm." (Hague Conference on Private International Law 2012).

\section{$2 \quad$ Same-sex Partners}

The need for cross-border reproductive medicine might arise in the case of samesex partners. If two woman are involved, they have accesss to ART in, for instance, UK and Sweden however majority of EU countries do not permit ART for same-sex partners. If two man are involved, they need a surrogate mother in order to have a child.

In UK HFEA (2008) regulates the situation of ART and its consequence on parenthood of the child born if two women are a party of the civil partnership (Sec 42-45). Certain conditions have to be met, called agreed female parenthood conditions. These conditions are: consent of both women to the treatment, consent of a woman who is not the mother to be treated as a parent, no notice of the withdrawal, no prohibited degrees of relationship in relation to these two women. If these conditions are met, parents of the born child are: the legal mother of the child is the woman who delivers the child and the other woman is treated as a legal parent of the child. In this situation there is no father.

In addition, HFEA regulates the situation of the child who has been carried by a woman as a result of placing in her an embryo after the death of the civil partner. The civil partner would be the legal parent of the child born if: the embryo was created at a time when the woman was a party to a civil partnership, the other 
party to the civil partnership consented in writing (and did not withdraw the consent) to placing an embryo in woman after the death of the other party, and to being treated as the parent of any resulting child, woman has elected in writing for the other party to the civil partnership to be the parent of the child, and no one else is to be treated as the father of the child, or as a parent of the child or the child is adopted (Sec 46 HFEA 2008).

Since 2005, Swedish law allows donor insemination and IVT for lesbian partners. In this situation the woman who delivers a child is the child's legal mother and the other woman is the legal parent ${ }^{1}$. This rule can be implemented only if the procedure is conducted in a state hospital. Consent to the procedure of the woman is a necessary condition for her to be considered a legal parent. Her parenthood is completely identical to the parenthood of the mother of the child. This is so in the situation of an existing registered partnership, but also if two women live together in a civil partnership. Fatherhood of the donor can not be established. The consent of the woman who is not a mother has to be given in writing in the presence of witnesses, it has to be approved by Social council and the mother. If there is no consent, the parenthood could be established by court decision.

\section{$3 \quad$ Woman without a Partner}

Donor insemination of the woman without a partner is a procedure which in family law has a consequence that the born child would not have a father, as it is not allowed to establish faterhood of a donor. The child would have just one parent, the mother.

From the family law aspect, the interest/right of the child to have both parents is recognized. If the single woman has an access to AID, this interest/right of the child would not be respected. On the other hand, one can argue that a single woman has reproductive rights including the right to AID. Whether a single woman would have the right to AID or not depends on which of these conflicting rights the legislator of a particular country considers more important: the interest/right of the child to have both parents or the single woman's right to AID.

In European comparative law, a single woman has an access to AID in Spain, Russia however this procedure is forbidden in Sweden, France, Austria ${ }^{2}$. In Serbia under Article 26/3 of the Act on Treatment of Infertility with Biomedically Assisted Fertilization Procedures (ATIBFP), as an exception a single woman is entitled to treatment of infertility with biomedical assistance. She is entitled to treatment of infertility with biomedical assistance if two ministers (minister for health and minister for family relations) give their consent and if there are particularly justified grounds ${ }^{3}$. 
The need for cross-border reproductive medicine might exists in the case of posthumous fertilization. This is the case of a woman who wants to be fertilized by husband's /partner's sperm after his death or to have an embryo transferred in her body after the death of her husband/partner. This procedure is permitted in, for instance UK and Greece; but forbidden in, for instance: France, Switzerland, Italy.

Since 2008, in the UK the family law consequence in the case of posthomous fertilization is that the man whose sperm is used in the conception of a child is considered to be the legal father. It is necessary to have his consent to posthomous fertilization by his sperm or his consent to transfer the embryo using his sperm before his death; including his consent to place the embryo in the woman after his death and the consent to being treated as the father of any resulting child. The consent must not be withdrawn. The condition on the woman's behalf is that she has elected in writing, no later than the end of the period of 42 days from the day on which the child was born, for the man to be treated as the father of the child. In addition, it is necessary that no-one else is to be treated as the father of the child or as a parent of the child or if the child is adopted (Sec 39 HFEA 2008).

However, according to earlier UK legislation (HFEA 1990) it was stipulated that: " the sperm of a man, or any embryo the creation of which was brought about with his sperm, was used after his death, he is not to be treated as a father of the child" (28. 6. b).

"This provision is inserted, as the Warnock report recommended, to ensure that estates can be administered with some degree of finality and to give effect to Warnock's expressed desire that fertilization of a woman following the death of her partner (or husband as Warnock would have limited it) should be actively discouraged. This they recommended because it may give rise to profound psychological problems for the child and the mother."(Morgan and Lee 1991: 156160). Eventually, after 18 years this stipulation is abandoned and replace with the rule that the man could be considered as the legal father of the child conceived after his death.

If embryo transferred after the death of the husband who did not provide sperm (donor insemination), but the embryo was created at a time when woman was a party to marriage, the other party to the marriage died before the placing of the embryo and the other party to the marriage consented in writing (and had not withdrawn the consent) to place the embryo in the woman after his death, and to being treated as the father of any resulting child, then the man is to be treated as the father of that child. Other conditions are: that woman has elected in writing no later than the end of the period of 42 days from the day on which the child was 
born for the man to be treated as the father of the child, and no-one else is to be treated as the father of the child or as a parent of the child or the child is adopted.

In Greece, assisted reproduction after the death of the husband or partner is allowed with the court's permission and only if certain conditions are met. These conditions are: husband or partner was ill and the illness could have had an impact on the conception or could endager his life; the husband or partner has given his consent to post mortem conception and the document is certified by public notary. Assisted reprodution is not allowed before 6 months after his death and more than two years after his death (Art 1457 Act 3089 on Medically assisted human reproduction) (Kovaček Stanić 2008: 211). ${ }^{4}$

The first case involving posthumous fertilization in Europe was the famous case Parpalaix c. Centre d'etude et de Conservation du Sperme. Following the death of her husband Mrs. Parpalaix requested his sperm from CECOS (Centre d'etude et de Conservation du Sperme) for the purpose of insemination. CECOS refused, claiming that no law mandated the return of the sperm. Mrs. Parpalaix went to court suing for possession of the sperm. The Court ordered CECOS to turn the sperm over to Mrs. Parpalaix and her doctor for insemination or destruction. Mrs. Parpalaix went abroad for fertilization, as French law does not permit posthumous fertilization, but fertilization was not successful (more in Jones1988). ${ }^{5}$

\section{$5 \quad$ Egg and Embryo Donation}

The need for cross-border reproductive medicine might arise in the case of egg or embryo donation. These procedures are forbidden in Switzerland, Italy, Austria, permitted in UK, France, Sweden, Greece. In some countries egg donation is permitted, but embryo donation is not (e.g. Slovenia).

In the case of egg donation, legal mother of the child is the woman who delivers the child (mater seper certa est etiam si vulgo conceperit). ${ }^{6}$ It is forbidden to establish maternity of the woman, who was the donor of egg cells. In France, for example, according to Bio-ethical laws which regulate egg donation, it is neccessary that parties give consent before a public notary or a judge, who has to inform all parties on paternity of the child born (L152-5). The requirement for gamete donors is to live in a heterosexual partnership and to have their own children. The consent is needed from the partner of the donors as well (L 673-2).

Italian Act 2004 forbids sperm and egg donation. However, on 9 April 2014 Constitutional Court declared these articles as unconstitutional which means that in the future sperm and egg donation should become allowed procedures in Italy; so Italian couples do not need cross-border medicine concerning gamete donation, any more. ${ }^{7}$ 
G. Kovaček Stanić: Comparative Analysis of ART in the EU: Cross-border Reproductive Medicine

One particular ART procedure results in the situation of a child who could have in fact two genetical mothers (if the nucleus from mother's fertilized egg is removed and inserted into an empty egg cell donated by another woman). The purpose of this procedure is two avoid genetic abnormalities in the mother's mitochondrial DNA (Deech and Smajdor, 2007).

In the case of embryo donation, no genetic links exist between a couple considered legal parents of the child and the child. The legal mother is the woman who delivers the child and her husband/partner is considered the legal father. According to, for example, Bio-ethical laws, the written consent of all persons involved in the procedure is needed. The judge has to decide on using the embryo from another couple, having in mind best interests of the future child (L152-5).

Some legislations, for instance, (Austrian) (Kovaček Stanič, 2008: 63) ${ }^{8}$ do not permit IVF in combination with gamete donation. IVF is permitted only using gamete from the couple involved in the proecedure (homologous procreation techniques). The case of S.H. and Others v. Austria concerns prohibition of gamete donation. ${ }^{9}$

"The applicants were two married couples. As they were infertile, they sought to have recourse to medically assisted procreation. The only means by which they could have a child of which one of them was the genetic parent was in vitro fertilisation (IVF) using sperm from a donor (in the case of the first couple) or eggs (in the case of the second couple). Both methods were illegal under the Austrian Artificial Procreation Act, which prohibited the use of sperm from a donor for IVF treatment and egg donation in general. That Act did, however, allow other methods of assisted procreation, in particular IVF using eggs and sperm from persons married to each other or living together as man and wife (homologous procreation techniques) and, in exceptional circumstances, sperm donation for in utero fertilisation. The applicants lodged an application with the Constitutional Court, which held that there had been an interference with their right to respect for their family life, but that this was justified because it was designed to preclude both the creation of unusual family relationships (a child with two mothers, one the biological mother and the other a "surrogate" mother) and the exploitation of women." 10

European Court of Human Rights has concluded that:

"Neither in respect of the prohibition of egg donation for the purposes of artificial procreation nor in respect of the prohibition of sperm donation for in vitro fertilisation under section 3 of the Artificial Procreation Act had the Austrian legislature exceeded the margin of appreciation afforded to it at the relevant time. Since the use of IVF treatment had given rise then and continued to give rise today to sensitive moral and ethical issues against a background of fast-moving medical and scientific developments, and since the questions raised by the case touched on areas where there was not yet clear common ground amongst the member States, 
the Court considered that the margin of appreciation to be afforded to the respondent State must be a wide one."11

"The Austrian Parliament had not thus far undertaken a thorough review of the rules governing artificial procreation, taking into account the relevant dynamic developments in science and society. The Austrian Constitutional Court had observed that medical science at the time and the consensus existing in society were subject to developments that the legislature would have to take into account in future. Although the Court had concluded that there had been no violation of Article 8 in the present case, it observed that the area in question, in which the law appeared to be continuously evolving and which was subject to particularly dynamic scientific and legal developments, needed to be kept under constant review by the Contracting States." 12

\section{Surrogate Motherhood}

Surrogate motherhood is a procedure in which a woman consents to pregnancy and to giving birth while intending to relinquish the child to others - to the couple who commissioned the pregnancy. ${ }^{13}$ The first published case of surrogate motherhood took place in Louisville, Kentucky, in November 1980. The woman who had carried and given birth to the child, which was conceived through artificial insemination by the sperm of the husband of an infertile woman, handed over the child to that husband and his wife and thus fulfilled her obligation. Some authors find the roots of this phenomenon in biblical times. ${ }^{14}$

There is a need for cross-border reproductive medicine concerning surrogate motherhood since in Europe surrogate motherhood is permitted in the United Kingdom (including surrogate motherhood for same-sex partners - two man), Greece, Ukraine, but prohibited in: Austria, France, Germany, Italy, Spain, Switzerland, Slovenia. In some countries there is no specific regulation on surrogacy. For instance, the Family Code of the Russian Federation permits surrogate motherhood by providing for registration of the commissioning couple as legal parents. Draft laws which would permit this practice exist in the Netherlands, Belgium, Finland, Sweden, Ireland, Serbia.

Transnational problems are acute in the case of surrogacy. It could be extremely complicated for intending parents - commissioning couple who have obtained a child from a surrogate mother in another country to return to their country with the child, because if their country prohibits or does not recognize surrogacy, their legal parentage may not be recognized. The consequence is a difficulty for the child to acquire nationality and get a passport of the country from which the commissioning parents came (parentless and stateless child). 
One can imagine an example: The intending parents presumably from Serbia, a country which does not permit surrogate motherhood, go to the country which permits this procedure. The intending mother's egg is fertilized with the sperm of her husband by IVF procedure and transferred to the surrogate mother who delivered the child and passed it over to the intending parents. In this country, the intending parents are legal parents, according to the law which regulates surrogate motherhood. They want to return to the country they come from ("receiving state") with the baby. First, they need a passport for the baby. How will they get it? They try in the Serbian Embassy in the country where the baby was born. In Serbia, as in most European states, nationality is acquired "by descent" where one of the child's legal parents is a national of that state. Are the intending parents legal parents according to law of Serbia as a "receiving state"? No, they are not. The legal mother is surrogate mother, as there is a rule that the mother is the woman who delivers the child (mater semper certa est). Her husband is legal father according to pater est quem nuptiae demonstrant rule. If she is not married, fatherhood should be established by acknowledgment or in court procedure. The baby cannot get the nationality of the state where it was born, as according to the law of that state legal parents are the commissioning couple who have Serbian nationality. One possibility would be to register the surrogate mother as a legal mother in the Serbian Consulate and after that, the intending father acknowledges his fatherhood with the permission of the legal mother (surrogate mother). Then, the child could acquire Serbian nationality, as his/her father is a Serbian national. After that, the surrogate mother could try to give the child to adoption. If she would succeed depends on the national law of the country where the baby was born. The intending mother could try to adopt the child as the wife of the legal father in Serbia. If she would succeed depends on many circumstances, one of the most important ones is how would Serbian authorities treat surrogate mother's intention to give child to adoption. The other possibility to resolve the problem is by applying private international law rules, for example, by recognizing the decision on parentage of the state where the child was born. The legal parents would be the intending parents according to the law of the country which permits surrogate motherhood. But, it is not sure that the receiving state would recognize this decision, as surrogate motherhood is forbidden and it could even be considered a practice which is against public policy of that country. This potential case shows how difficult it would be to establish legal parentage of the commissioning couple in the receiving state which does not permit surrogate motherhood.

An obstacle for cross-border surrogate motherhood procedure is legal requirement for the intending parents and/or the surrogate mother to have habitual residence (or domicile) in the country where the procedure is going to be performed. In Europe, this requirement exists in laws of Greece and UK, which is specifically designed to prevent "reproductive tourism". 
Thus, the states to which intending parents travel include Eastern Europe, Asia and North America, states which do not have habitual residence (or domicile) as legal requirement. The number of international surrogacy arrangements even is impossible to determine globally. However, data from five agencies specialising in international surrogacy shows a tremendous growth in the "market": when comparing 2010 to 2006 , the figures demonstrate a percentage increase of nearly $1,000 \%$ across the agencies." 15

One case describes the plight of an infertile Norwegian would-be mother (aged 45) who traveled to India in 2009 and selected an egg from an Indian donor there and arranged for it to be fertilized with the sperm from an unrelated Scandinavian donor. The fertilized egg was then implanted in the womb of an anonymous surrogate mother. The surrogate mother gave birth to twin boys. The commissioning Norwegian woman sought to bring the boys back to Norway, but Norway refused them travel documents. Norwegian authorities took the view that the surrogate mother was the legal mother. Norwegian officials also refused to recognize the boys as Norwegian citizens or to allow them "adoption rights." Indian officials took the view that the woman who had commissioned the child was the mother and refused to accept the twins as Indian nationals. Eventually, the children were allowed to enter Norway. According to the Norwegian Immigration Act (subsection 76), the Ministry of Justice and the Police may exercise discretion in particular cases in order to safeguard fundamental national interests or based upon foreign policy considerations. On the basis of instructions from the Ministry of Justice and the Police, in April 2011, and in the exercise of powers under the Immigration Act (subsection 7), the Directorate of Immigration granted the children a residence permit. Nevertheless, the Directorate of Immigration's grant of a residence permit did not resolve the questions of citizenship, parenthood, and adoption. ${ }^{16}$

Another case described in family law literature is the case of a Japanese baby Manji Yamada. A couple from Japan came to India, signed the agreement with surrogate mother from India. The fertilization process of eggs with the sperm from the couple was completed in Tokyo and the embryo was transferred to surrogate mother in India where a baby was born. However, a month before the baby was born the couple divorced, and ex-wife disowned the child. Surrogate mother also abandoned the child. The biological father had come to India to take custody, but had to return to Japan and never made a formal application seeking custody of the child. The child's grandmother, against the deriction of the High Court (Rajasthan) filed a writ petition in the Supreme court seeking custody of the child. It was contended in the Supreme Court that under the National Guidelines for Accreditation, Supervision and Regulation of ART Clinics in India 2005 the surrogate child is the legitimate child of its genetic parents. The Supreme Court of India disposed of the writ petition filed by the grandmother with directions that, if any person has any grievance or complaint relating to the child, it can be vented in 
accordance with the Commission for Protection of Child Rights Act 2005. Following the directions of the Supreme Court, the Regional Passport Office issued an "Identity Certificate" to the baby allowing her to travel to Japan, but the baby's citizenship status remained unclear. The baby and her grandmother who had been looking after her left India for Japan. ${ }^{17}$ This case is an example of the child conceived by ART and born by a surrogate mother, who becomes parentless and stateless.

The Hague Conference on private international law is working on the issues of international surrogacy arrangements. The Permanent Bureau has drawn up two Preliminary Reports, first Preliminary Report on private international law issues surrounding the status of children, including issues arising from international surrogacy arrangements 2011 and second, Preliminary Report on the issues arising from international surrogacy arrangements 2012. In 2014 the Permanent Bureau would expect to produce a Final Report on this with recommendations as to the appropriate next steps. ${ }^{18}$

In the second document it is stated:

"The ultimate 'need' is therefore for a multilateral instrument which would put in place structures and procedures to enable States to ensure that these obligations are being met in the context of this transnational phenomenon. This would include seeking to eliminate 'limping' legal parentage, ensuring children are able to acquire a nationality, ensuring their right to know their identity is secured and putting in place procedures to ensure that they are protected from harm. One possible approach to resolving the difficulties regarding the legal parentage of children born as a result of international surrogacy arrangements may be to consider the issue within the broader context of a comprehensive future instrument concerning the private international law aspects of the establishment and contestation of legal parentage. Such an instrument might contain, for example, uniform rules on the jurisdiction of courts or other authorities to make decisions on legal parentage which have general effect, uniform rules on the applicable law, corresponding rules providing for the recognition and enforcement of such decisions (or authentic acts, e.g. a birth certificate), uniform rules on the law applicable to the establishment of legal parentage by operation of law or by agreement and applicable law or recognition principles concerning the establishment of parentage by voluntary acknowledgement. A second possible approach to resolving the difficulties arising from international surrogacy arrangements would be to consider the matter as a discrete, "burning issue" which requires a methodology which is more specific in focus and yet broader in the techniques employed to resolve the issues. Such an approach might involve looking to the 1993 Convention, although there are obvious and important differences between international surrogacy and intercountry adoption. For example, there is at the moment no similar set of agreed international principles relating to international surrogacy and it might therefore be difficult to find common principles for an international system. Since some States currently 
prohibit the use of surrogacy arrangements, this could be seen as incompatible with a discussion concerning the regulation of international surrogacy arrangements. It is important to recognise, however, that creating safeguards around a system and finding solutions for the challenges it poses, does not necessarily entail facilitating and promoting such a system. This is indeed a common denominator between international surrogacy and intercountry adoption. Contracting States to the 1993 Convention are not bound to engage in any particular level of intercountry adoption. In the same way, an instrument setting a framework for co-operation and the prevention of abuses, with the goal of protecting the rights and interests of children, must be distinguished from an effort to promote international surrogacy. All States may consider that they have an interest in effectively regulating international surrogacy in order to protect the rights and interests of those involved, as well as to ensure that situations which are effectively a 'fait accompli' with all the consequent difficulties and concerns, are minimised."

\subsection{Legislations which Permit Surrogate Motherhood}

The Preliminary document recognises two groups of regulations enacted depending on the types of regulation. "The first group applies a process of 'preapproval' of surrogacy arrangements, whereby the prospective intending parents and the surrogate mother must present their arrangement to a body to be approved before the arrangement and medical treatment may proceed. The bodies are required to verify that the conditions of the legislation have been met. In the second group, regulation relates only to putting in place a set procedure for the intending parents to obtain legal parentage for a child born as a result of a surrogacy arrangements ex post facto. Here the focus is on the transfer of legal parentage post-birth, and the process usually includes a retrospective consideration of the arrangement to determine whether the conditions of the legislation have been met such that a 'parental order' (transferring legal parentage) may be made."

For example, in the first group there is legislation of Greece and in second there is legislation of the United Kingdom.

In 2002, Greece adopted the Medically Assisted Reproduction Act, which became part of the Civil Code. ${ }^{19}$ Surrogacy in which the surrogate mother is not the genetic mother is only permitted (gestational surrogacy), and it can have two forms. In the first, the ova of the woman who wants to have the child is used, and in the second when the ova of a third woman is used. Surrogate motherhood is permitted only if court approves it. The Act includes requirements that have to be fulfilled for permitting surrogate motherhood. The first is medical, the woman who wants the child has to be incapable of carrying a child, and there has to be a medical proof for it. In case the woman wants to avoid pregnancy for another 
reason, surrogate motherhood would not be permitted (aesthetic, professional reasons). The other requirement is also of medical nature, the woman who will carry out the pregnancy has to be medically capable of doing it, for which she needs medical proof. The third requirement is that the court is presented with a written agreement between the parties (which must not include payment). The parties in the agreement are the persons who want the child, the woman who will give birth to the child and her husband, if the woman is married. The fourth requirement is that the fertilized ova implanted in the woman who is going to carry out the pregnancy must not be hers (gestational surrogacy, traditional is not permitted). The last requirement, as mentioned earlier, is that the woman who wants the child and the woman who is going to give birth to the child are Greek residents, and thus "reproductive tourism" is avoided, i.e. the arrival of women from other countries in Greece with the sole purpose of participating in this type of assisted reproduction.

In the United Kingdom there are two acts regulating surrogate motherhood. The first is the Surrogacy Arrangements Act from 1985, and the other Human Fertilisation and Embryology Act from $1990 .{ }^{20}$ Both legal acts were amended by the Human Fertilisation and Embryology Act from 2008. Amendments widened the circle of people who have the right to the surrogate motherhood procedure, so that homosexual couples who, according to the law of the UK can form a civil partnership, have the same right, as well as transsexuals, individuals who have changed their sex, and who are permitted to form matrimony (Welstead, 2011). According to the law of the United Kingdom, the surrogate mother is the mother of the child, but the couple who ordered the child could be considered the child's parents on the basis of a court decision. This request can be submitted by: a married couple, a couple that has entered a civil partnership, even a couple who lives together through permanent family relationships, but only if there is no relation of prohibited degree between them, while a person without a partner cannot submit such a request. Two men who live in a homosexual relationship can be approved as parents of the child born by a surrogate mother since April 6, 2010 (article 54 of the Human Fertilisation and Embryology Act).

The basic requirement for partners or a married couple to be considered parents of the child is the genetic connection with the child. It is necessary for at least one of them to be the genetic parent of the child, i.e. that the gametes of at least one of them were used for conception. Regardless of whether the genetic material comes from both of them or only one of them, both can be treated as legal parents. The request has to be submitted to the court within six months from the birth of the child. There are also particular conditions that have to be met in order for the court to make such a decision. Those are: the home of the child has to be with the commissioning couple who submited the request, they, or at least one of them, as mentioned earlier, have to be residents of the UK, and they have to be at least 18 years old. Apart from this, the court has to be convinced that the father of the child, if the father is not submitting the request, and the woman who carried the 
child, have freely, consciously and unconditionally agreed for such a decision to be made, unless they cannot be found or are incapable of giving statements. "Time for consideration" is also included for the woman who carried the child, so the agreement is not considered valid if less than six weeks have passed from the birth of the child. Also, the court has to be convinced that money or other favours, other than reasonable expenses, have not been provided. ${ }^{21}$ If all these requirements are met, the court will decide whether to award the parental rights or not, considering the wellbeing of the child as the most important criterion.

In Ukraine the parentage of the child in the case of surrogate motherhood is regulated into Family Code of Ukraine, art. 123/2,3. It is stipulated that in the case of trasfering the embryo in another woman, if the embryo is conceived by spouses (man and woman) as a result of ATP, the parents of the child are spouses (art. 123/2); if the embryo is conceived by another woman's husband and other woman as a result of ATP, the spouses acknowledge parentage of the child. The procedure of usage of the ART is regulated by the Order on the procedure of usage of the ART. Surrogate motherhood is regulated in the Part VI of this Order. According to art. 6.1. only gestational (full) surrogacy is permited, as it is said that the surrogate mother should not have a genetical tie with the child. It is permitted to use eggs from parent's relatives (mother, sister, sister in law etc.). Surrogate mother has to be an adult, capable woman who has a healthy child of her own. Before the surrogate motherhood as a medical procedure is started, the surrogate mother and woman (man) or both spouses have to make a public notary agreement. The condition of habitual residence/domicile in Ukraine for the intending parents is not stipulated. Thus, Ukraine could be and it is the country of reproductive tourism to obtain surrogate motherhood procedure. ${ }^{22}$

\subsection{Legislations which do Not Permit (Prohibit) Surrogate Motherhood ${ }^{23}$}

In a certain number of European countries surrogate motherhood is expressly prohibited (Germany, Austria, France, Italy, Spain, Switzerland, Slovenia, Serbia).

According to the Embryo Protection Act of Germany from 1990, artificial insemination of a surrogate mother and the transfer of embryo into the body of a surrogate mother is prohibited and punishable. The reform in the area of parenthood in Germany and the Parentage Law Reform Act from 1997 explicitly determine that the mother of the child, with the allusion to modern medical science, is the woman who gave birth to the child, without a statement about the permission of donating ova or embryos (par. 1591) (Frank, 1997). The woman who has given birth to the child is automatically qualified as the legal mother. The only way for this to be changed is adoption of the child. In the context of surrogate motherhood, general rules lead to the same conclusion. The surrogate mother who has given birth to the child becomes the legal mother regardless of whether she became one using artificial insemination, in vitro fertilisation, a transfer of embryo or in some 
other way. In case of surrogacy agreements in a foreign country involving a German couple and a surrogate mother from a foreign country, according to Rolf Wagner: "So far as the example just given a German intended mother is supposed to be regarded in a foreign decision as the mother of a child in the legal sense, recognition of that decision would most likely be thwarted by the order public reservation in s 109, subsection (1) No 4 FamFG. The cited provisions, leading to the invalidity of surrogacy agreements under German law, are of such fundamental nature that divergence from these provisions would normally and most likely lead to violation of the German order public." (Wagner, 2012: 130131).

The Austrian Law on Reproductive Medicine ("Fortplanzungsmedizingesetz"), which was passed by the Austrian Parliament in 1992, bans the surrogacy method. Though surrogate motherhood is not mentioned explicitly, the law stipulates that ova can only be used by the woman from whose body they were retrieved. Moreover, according to $\S 137 \mathrm{~b}$ of the Republic of Austria Civil Code, the mother of a child is always the woman who gave birth to this child, that is, - the surrogate mother - and not the contractor of surrogacy. Hence, the Austrian law prohibits a transfer of a fertilised ova to another woman's body and defines the woman who gives birth to a child as the mother of a child. Since its enactment in 1992, the law has been slightly amended. However, changing the law in such a way as to allow surrogacy has never come up as an issue. ${ }^{24}$

The so-called Bio-Ethical Acts, passed in France in 1994, strictly prohibit surrogacy, regardless of whether it is commercially based or not. The child born in this way could not be adopted by the commissioning couple. The Act nullifies all the contracts whose subject is procreation or gestation for another person. The law of 2011 remains silent on this procedure, which thus remains prohibited (Centre de droit da la famille, 2012).

In the Constitution of Switzerland, the article 24 introduces a number of strict principles regarding conception with bio-medical support. One of them is the prohibition of surrogate motherhood, the other limitation of artificial procreation to cases of infertility and existence of a serious hereditary illness etc (Centre de droit da la famille, 2012).

The Act of Treatment of Infertility and Procedures of Insemination with BioMedical Support, passed in Slovenia in 2000, prohibits surrogate motherhood (nadomestno materinstvo). It is stipulated that the woman who intends to give her child to a third person after delivery has no right to the procedure of fertilisation with bio-medical support, with or without monetary compensation (art. 7). ${ }^{25}$

At present the statutes of Serbia do not permit surrogate motherhood. The Act of Treatment of Infertility with Biomedically Assisted Fertilization Procedures (ATIBFP) explicitly prohibits the practice. Indeed, the ATIBFP provides for a 
prison sentence of between three and ten years for a surrogate mother and for a person who offers surrogate motherhood services (regardless of whether financial or any other kind of gain is involved). ${ }^{26}$

\section{$7 \quad$ Conclusion}

It is obvious that there is a need for cross-border reproductive medicine for several reasons. Some are due to the fact that some states do not permit particular ART procedures; thus couples travel to the state where needed procedure is allowed (surrogate motherhood, egg, embryo donation, posthumous fertilization). Other situations are due to the fact of who is entitled to ART procedures. In some states ART procedures are not allowed to same-sex couples or a single woman.

The obstacle for having cross-border reproductive medicine ("reproductive tourism") is legal requirement of habitual residence (domicile) of the state where procedure is to be performed, for the parties involving in the procedure. However, this requirement does not exist in all legislations, so persons who need the ART procedure go there and perform the procedure. The consequence might be that the born child becomes parentless ("limping legal parentage") and stateless. Since the best interest of the child is the paramount principle in contemporary family law, it is most important to find solutions for these situations.

The Hague Conference on private international law is working on issues of international surrogacy arrangements with the conclusion:

"The number of international surrogacy arrangements appears to be growing at a rapid pace and while some States are attempting to resolve the problems arising as a result, this global phenomenon may ultimately demand a global solution. There is no doubt that the current situation is far from satisfactory for the States and parties involved and, most importantly, for the children born as a result of these arrangements. There is a real concern that the current situation often fails to adequately ensure respect for children's fundamental rights and interests."

\section{Acknowledgment}

This article is a contribution to the project Biomedicine, Environmental Protection and the Law, financed by the Ministry of Education, Science and Technological Development of Serbia.

\footnotetext{
Notes

${ }^{1}$ Code on children and parents (1949:381) (Föräldrabalken), amanded by: SFS 2005:434, Insemination Act (1984: 1140, SFS 2005:443) and Act on fertilization outside the body (1988:711, SFS 2005:445), Maarit Jänterä-Jareborg, Sweden: Lesbian Couples are Entitled to Assisted Fertilization - towards Equal Legal Rights for Homosexual Couples, Zeitschrift für das gesamte Familienrecht (FamRZ), 2005.
} 
2 On legislation of EU countries: UK: Morgan, Lee Blackstone's Guide to the Human Fertilisation and Embryology Act 1990, London: Blackstone Press Limited, 1991; France: Bio-ethical laws, Law 1 July 1994, two laws July 1994, amended in 2011, Jacqueline Rubellin-Devichi, Reforms and Controversies, The International Survey of Family Law, A. Bainham (ed.), 1994, p. 241; Austria: Erwin Bernat, Erich Vranes, The Austrian Act on Procreative Medicine: Scope, Impacts and Inconsistencies, D. Evans (ed.) Creating the Child, 1996, p. 241; Switzerland: Olivier Guillod, A New Divorce Law for the New Millenium, The International Survey of Family Law, A. Bainham (ed.), 2000; Sweden: Åke Saldeen, The Children Ombudsman, Adoption by Homosexual Partners and Assisted Reproduction, The International Survey of Family Law 2004, A. Bainham (ed.); The Netherlands: Artificial Insemination (Donor Information) Act, Act of 25 April 2002, Bulletin of Acts and Decrees 240.3

${ }^{3}$ Zakon o lečenju neplodnosti postupcima biomedicinskog začeća (Act on Treatment of Infertility with Biomedically Assisted Fertilization Procedures), art. 56/25 and art. 73, Official Journal of Republic of Serbia 72/2009.

${ }^{4}$ Law 3089/2002, Translation of the Law to Serbian in: Kovaček Stanić, Legislativa o ljudskoj reprodukciji uz biomedicinsku pomoć, 2008, Centar za zdavačku delatnost Pravnog fakulteta u Novom Sadu, p. 211.

${ }^{5}$ More in: David Jones, Artificial Procreation, Societal Reconception: Legal Insight from France, The American Journal of Compartive Law 3/1988.

${ }^{6}$ This rule originates from Roman law: Digesta, 2,4,5 (Paul. 4. ed.) ni med viri

${ }^{7}$ B92 news 9 April 2014. Italian Act - Norme in materia di procreazione medicalmente assistita No 40/2004, (Norms on medically assisted procreation), Italian Official journal No 45/2004, translation to Serbian in op. cit. Kovaček Stanić Legislativa, p. 223. More in: Antonello Miranda, In vitro veritas? The New Italian Human Fertilization and Embryology Act 2004: Legal Iddues between Balancing of Individual Interests and Social Priorities, Family Law: Balancing Interests and Pursuing Priorities (ed. L. Wardle \& C.S: Williams, 2007, p. 270.

8 Artificial Procreation Act 1992, translation to Serbian in: op. cit. Kovaček Stanić, Legislativa, p. 63.

${ }^{9}$ Information Note on the Court's case-law No. 146.

${ }^{10}$ Ibidem.

${ }^{11}$ Ibidem.

${ }^{12}$ Ibidem.

${ }^{13}$ See more about this in Kovaček Stanić, State Regulation of Surrogate Motherhood: Liberal or Restrictive Approach, International Journal of the Jurisprudence of the Family 4/2013 and in Kovaček Stanić, Porodičnopravni aspekt biomedicinski potpomognutog oplođenja u pravu Srbije i evropskim pravima [Family Law Aspects of Biomedically Assisted Conception in Serbian Law and European Laws], ZBORNIK MATICE SRPSKE ZA DRUŠTVENE NAUKE [SOCIAL SCIENCES QUATERLY], No. 131 (2010). For an overview of practices of gamete donation and the fertility industry in the United States, see Naomi Cahn, The NewKinship: Constructing Donor-Conceived Families (2013), especially chapter 1.

${ }^{14}$ Sarah, Abraham's wife, who could not have children, talked Abraham into taking the concubine Hagar, and from that relationship a son, Ishmael, was born. This might be considered an instance of surrogate motherhood, since the plan was no doubt for the child to be turned over to Abraham and Sarah rather than to be raised by Hagar. (Hagar could not refuse the offer because she was Sarah's slave.) Genesis 16.

15 "E.g., whilst only a "snapshot", the information obtained by the Aberdeen University research project ...from five "agencies" that specialise in international surrogacy (based in 
the United States of America, India and the United Kingdom), evidences that international surrogacy arrangements have been entered into by intending parents resident in Europe, Australasia, North and South America, Asia and Africa." (Hague Conference on private international law, 2012)

${ }^{16}$ See, e.g., Sumitra Deb Roy, Stateless Twins Live in Limbo, THE TIMES OF INDIA, Feb. 2011, 2, http://articles.timesofindia.indiatimes.com/2011-0202/mumbai/28374760_1_fertility-clinic-twins-crime-branch,

http://www.nrk.no/nordland/kari-ann-volden-far-komme-hjem-1.7596488). See also (Curry-Sumner and Vonk, 2011).

${ }^{17}$ More on this case and Indian law in (Malhotra and Malhotra, 2013: 151-174).

${ }^{18}$ Available at http://www.hcch.net, last visited 1 April 2014.

19 Law 3089/2002, Efie Kounougeri-Manoledaki, Surrogate Motherhood in Greece (According to the New Law on Assisted Reproduction), The International Survey of Family Law, A. Bainham (ed.), 2005. Translation of the Law to Serbian in: op. cit. Kovaček Stanić Legislativa, p. 211.

20 Surrogacy Arrangements Act 1985, Human Fertilisation and Embryology Act 1990. Human Fertilisation and Embryology Act, 2008, available at: http://www.legislation.gov.uk/ukpga/2008/22/contents.

${ }^{21}$ Article 30 of the Act, op. cit. Morgan, Lee, pp. 153-154.

${ }^{22}$ Legal aspects of surrogacy in Ukraine are regulated by Ukrainian Family Code, art. 123 (No. 524-V, amended December 22, 2006), available at:http://www.familylaw.com.ua/index.php?option=com_content\&view=article\&id=68\&Ite mid=97\&lang=enНАКАЗ, 09.09.2013 № 787, Зареєстровано в Міністерстві юстиції України 2 жовтня 2013 р. за № 1697/24229, Про затвердження Порядку застосування допоміжних репродуктивних технологій в Україні, available at http://na.spinform.ru/ (last visited 27 February 2014).

${ }^{23}$ Op. cit. Kovaček Stanić, State Regulation of Surrogate Motherhood.

${ }^{24}$ Op. cit. Bernat, Vranes p. 241.

${ }^{25}$ The Act stipulates a penalty for the legal officer who would carry out the procedure of surrogate motherhood (between 500.000 and 5.000000 Tolars) and for the person who would participate in the group of bio-medical experts (between 50.000 and 150.000 Tolars). ${ }^{26}$ Op. cit. Zakon o lečenju neplodnosti postupcima biomedicinskog začeća art. 56/25 and art. 73.

\section{References}

Bernat, E. \& Vranes, E. (1996) The Austrian Act on Procreative Medicine: Scope, Impacts and Inconsistencies, In: Evans, D. (ed.) Creating the Child, (Netherlands: Kluwer Law International).

Cahn, N. (2013) The New Kinship: Constructing Donor-Conceived Families (New York: New York University Press).

Chaves, M. (2011) Homoeffective Parentage in Relation to Medically Assisted Reproduction: A Paralel betwen Brazil and Portugal, In: Atkin, B. (ed.) The International Survey of Family Law (Bristol: Jordan Publishing Limited).

Centre De Droit Da La Famille (2012) A Chronicle of Family Law in 2011, In: Atkin, B. (ed.) The International Survey of Family Law (Bristol: Jordan Publishing Limited).

Curry-Sumner, I. \& Vonk, M. (2011) National and International Surrogacy: An Odyssey, In: Atkin, B. (ed.) The International Survey of Family Law (Bristol: Jordan Publishing Limited).

Curry-Sumner, I. \& Vonk, M. (2012) National and International Surrogacy: Something 
MEDICINE, LAW \& SOCIETY

G. Kovaček Stanić: Comparative Analysis of ART in the EU: Cross-border Reproductive Medicine

Old, Something New, Something International and Something Asked, In: Atkin, B. (ed.) The International Survey of Family Law (Bristol: Jordan Publishing Limited).

Cvejić Jančić, O. (2011) A Child's Origin and Parenting, International Journal of the Jurisprudence of the Family, 2, available at: http://ssrn.com/abstract=2029121 (April 17, 2015).

Dethloff, N. \& Ramser, C. (2007) Tension Between Legal, Biological and Social Conceptions of Parentage in German Law, In: Shwenzier, I. (ed.) Tension Between Legal, Biological and Social Conceptions of Parentage (Cambridge: Intersentia).

Deech, R. \& Smajdor, A. (2007) From IVF to Immortality: Controversy in the Era of Reproductive Technology (Oxford: Oxford University Press).

Draškić, M. (1992) Porodičnopravni aspekti artificijelne inseminacije, Anali Pravnog fakulteta Beograd, 43(4), pp. 239-264.

Fitzgibbon, S. (2012) The Biological Basis for the Recognition of the Family, boston College Law School Legal Studies research Paper No. 274 (Boston: boston college Law School).

Frank, R. (1997) Parentage Law Reformed, In: Bainham, A. (ed.) The International Survey of Family Law (The Hague, Boston, London: Martinus Nijhoff Publishers).

Guillod, O. (2000) A New Divorce Law for the New Millenium, In: Bainham, A. (ed.) The International Survey of Family Law (Bristol: Family Law).

Hague Conference on Private International Law (2012) A Preliminary report on the issues arising from international surrogacy arrangements: Preliminary Document No 10 of March 2012, available at: http://www.hcch.net/upload/wop/gap2012pd10en.pdf (June 2, 2015).

Jones, D. (1988) Artificial Procreation, Societal Reconception: Legal Insight from France, The American Journal of Comparative Law, 36(3), pp. 525-545, doi: 10.2307/840345.

Jović, O. (2005) Surogat materinstvo - nova dimenzija roditeljstva (Beograd: Zadužbina Andrejević).

Cahn, N. R. (2013) The New Kinship: Constructing Donor-Conceived Families (New York, London: New York University Press).

Kounougeri-Manoledaki, E. (2005) Surrogate Motherhood in Greece (According to the New Law on Assisted Reproduction), In: Bainham, A. (ed.) The International Survey of Family Law (Bristol: Family Law).

Kovaček Stanić, G. (2008) Legislativa o ljudskoj reprodukciji uz biomedicinsku pomoć (Novi Sad: Centar za izdavačku delatnost - Pravni fakultet).

Kovaček Stanić, G. (2010) Porodično pravo: partnersko, dečje i starateljsko pravo (Novi Sad: Centar za izdavačku delatnost - Pravni fakultet).

Kovaček Stanić, G. (2010a) Porodičnopravni aspekt biomedicinski potpomognutog oplođenja u pravu Srbije i evropskim pravima, Zbornik Matice srpske za društvene nauke, 131, pp. 415-430, doi: 10.2298/ZMSDN1031415K.

Kovaček Stanić, G. (2011) Autonomija versus materijalna istina u komparativnom pravu o porodičnom statusu deteta, Zbornik Pravnog fakulteta u Novom Sadu, 45(3), pp. 195222, doi: 10.5937/zrpfns1103195K.

Kovaček Stanić, G. (2013) Biomedicinski potpomognuto začeće i rođenje deteta: Surogat materinstvo u uporednom evropskom pravu i Srbiji, Stanovništvo, 51(1), pp. 1-21, doi: 10.2298/STNV1301001K.

Kovaček Stanić, G. (2013) State Regulation of Surrogate Motherhood: Liberal or Restrictive Approach, International Journal of the Jurisprudence of the Family, 4, available at: http://ssrn.com/abstract=2343652 (June 6, 2015).

Macintosh, K. L. (2011) Illegal Beings: Human Clones and the Law (Cambridge: Cambridge University Press). 
Malhotra, A. \& Malhotra R. (2013) Law and Surrogacy Arrangements in India, , In: Atkin, B. (ed.) The International Survey of Family Law (Bristol: Jordan Publishing Limited).

Miranda, A. (2007) In vitro veritas? The New Italian Human Fertilization and Embryology Act 2004: Legal Iddues between Balancing of Individual Interests and Social Priorities, In: Wardle, L. D. \& Williams, C. S. (eds.) Family Law: Balancing Interests and Pursuing Priorities (Buffalo, New York: William S. Hein).

Morgan, D. \& Lee, R. G. (1991) Blackstone's Guide to the Human Fertilisation and Embryology Act 1990: Abortion and embryo research, the new law (London: Blackstone Press Limited).

Rubellin-Devichi, J. (1994) Reforms and Controversies, In: Bainham, A. (ed.) The International Survey of Family Law (The Hague, Boston, London: Martinus Nijhoff Publishers).

Saldeen, A. (2004) The Children Ombudsman, Adoption by Homosexual Partners and Assisted Reproduction, In: Bainham, A. (ed.) The International Survey of Family Law (The Hague, Boston, London: Martinus Nijhoff Publishers).

Wagner, R. (2012) International Surrogacy Agreements: Some Thoughts from a German Perspective, International Family Law, Special Issue, pp. 129-132.

Welstead, M. (2011) Child is My Child: This Child is Your Child; This Child was made for You and Me - Surrogacy in England and Wales, In: Atkin, B. (ed.) The International Survey of Family Law (Bristol: Jordan Publishing Limited). 